\title{
In Situ Production of Silver Bio Nanoparticles from Marine Biosurfactant Bacteria and Evaluation of Its Antibacterial Activity
}

\author{
M. Indhuja ${ }^{1}$, D. Kavitha ${ }^{2}$, P.Selvamaleeswaran ${ }^{3}$, A. Palanisamy ${ }^{4}$, M. Sureshkumar ${ }^{5}$ \\ ${ }^{1,2,3,4}$ Dept. of Biotechnology, Muthayammal College of Arts \& Science, Rasipuram, Tamil Nadu, India-637 408 \\ ${ }^{5}$ Dept. of Zoology, Muthayammal College of Arts \& Science, Rasipuram, Tamil Nadu, India-637 408 \\ *Corresponding Author: ibtkavitha.d@gmail.com
}

Available online at: www.isroset.org

Received: 25/Sept/2019, Accepted: 15/Oct/2019, Online: 31/Oct/2019

\begin{abstract}
BIOSURFACTANTS FROM MICRORGANISMS Biosurfactants are the surface-active molecules synthesized by microorganisms. With the advantage of environmental compatibility, the demand for biosurfactants has been steadily increasing and may eventually replace their chemically synthesized counterparts. Marine biosurfactants produced by some marine microorganisms have been paid more attention, particularly for the antimicrobial activity against various microbes in medicinal field. In this study, the screening of biosurfactant-producing marine microorganisms, the determination of biosurfactant activity as well as the recovery of marine biosurfactant and the antibacterial activity of the biosurfactant were done. The uses of silver nanoparticles with marine biosurfactants for the antibacterial activity also discussed. The marine Serratia $s p$. had the ability to produce the biosurfactant and shows high amount of antibacterial activity against some pathogenic bacteria.
\end{abstract}

Keywords: Biosurfactant, marine microorganisms, Silver nanoparticles

\section{INTRODUCTION}

Marine environment is the largest habitat as compared to other habitat in the biosphere. About $70 \%$ of the earth surface is covered by salt water. It is believed that the life is originated first from ocean. Biosurfactants are amphiphilic agents which, by accumulating at interface between immiscible phases, can reduce surface and interfacial tensions produced by bacteria, fungi and yeast, which either adhere to the cell surfaces or are excreted extracellular in the growth medium. They belong to various classes including glycolipids, lipopeptides, fatty acids, phospholipids, neutral lipids and lipopolysaccharides. The best biosurfactants can lessen the surface tension of water from 72 to $30 \mathrm{Nm}^{-1}$. The large surface-to-volume ratio enables many bacterial species to produce several types of structurally diverse surfaceactive compounds, which having antimicrobial, antiviral, haemolytic, and anti tumour activity [1]. During the last decades, there has been a growing interest in isolating microorganisms that produce surface active molecules with good surfactant characteristics such as low critical micelle concentration (CMC) and high emulsification activity, simultaneously presenting low toxicity and good biodegradability. Generally the type and amount of the biosurfactants, produced by microbes depends on the producer organism, factors like carbon and nitrogen, trace element, temperature. They are also classified into two different categories on the basis of their molecular weight: Low molecular weight biosurfactants are lipopeptides, glycolipids and phospholipids (having lower surface and interfacial tension) and high molecular weight biosurfactants are polymeric and particulate surfactants (more efficient as emulsion stabilizing agents) [2].

The silver nanoparticles coated textiles with enhanced functionalities, such as antibacterial, antistatic and UV protection, are greatly appreciated by a more discerning and demanding consumer market for high-value-added products. Silver nanoparticles can be exploited in medicine for burn treatment, dental materials, coating stainless steel materials, textile fabrics, water treatment, sunscreen lotions, etc. and possess low toxicity to human cells, high thermal stability and low volatility [3]. Antibacterial finishes are applied to gauge cloth for the major reasons is to control the spreading of disease through microorganism and avoid the danger of injury-induced infections.

\section{MATERIALS AND METHODS}

\section{Sample collection:}

Marine water samples were collected from different locations Marina beach, Chennai, Tamilnadu, India. The samples were collected in different sterile glass bottles, and immediately transported to laboratory for further analysis. 
Isolation of biosurfactant producing bacteria:

The marine water sample was spread on nutrient agar plate by using the serial dilution process. The dilutions of $10^{-3}, 10^{-}$ $4,10^{-5}, 10^{-6}$ dilutions were spread on the nutrient agar plate with salt. Then it had been incubated for 28 hours. After incubation individual colonies had been grown in different morphology.

\section{Screening of biosurfactant producing bacteria:} Cetyltrimethyl ammonium bromide (CTAB) methylene blue agar method

The bacterial isolates were inoculated on to MSM agar plates supplemented with $2 \%(\mathrm{w} / \mathrm{v})$ glucose, $0.25 \% \mathrm{w} / \mathrm{v}$ yeast extract and containing $200 \quad \mathrm{mg} \mathrm{l}^{-}$ ${ }^{1}$ cetyltrimethylammonium bromide (CTAB), a cationic surfactant and $5 \mathrm{mg} \mathrm{l}^{-1}$ methylene blue. The plates were incubated at $30^{\circ} \mathrm{C}$ for $24-48 \mathrm{~h}$ to observe dark blue halo. The clear zones are due to accumulation of methylene blue around the colonies of cells producing anionic surfactant.

\section{Determination of the Emulsification Index}

A mixture of $2 \mathrm{~mL}$ supernatant and $3 \mathrm{~mL}$ kerosene (or diesel) was vertically stirred for $2 \mathrm{~min}$ and the height of the emulsion layer was measured after $24 \mathrm{hr}$ to determine the emulsification index. The equation used to determine the emulsification index $\left(\mathrm{E}_{24}(\%)\right)$ is as follows:

The $\mathrm{E}_{24}(\%)=$ (height of emulsion layer/ height of total solution) $* 100 \%$

\section{Blood haemolysis test:}

Blood agar haemolysis method was used to screen biosurfactant producing strain. The method was based on the fact that biosurfactants were able to haemolysis the red blood cell present in blood. The selected isolates were incubated on blood agar plates incubated for 24- 48 hours at $37^{\circ} \mathrm{C}$. The zone of haemolysis indicated the production of biosurfactant.

\section{Biochemical characterization of isolated bacteria: Extraction of biosurfactant}

The culture was centrifuged at $5000 \mathrm{rpm}$ at $4^{\circ} \mathrm{C}$ for 30 minutes to obtain the supernatant. To the supernatant, equal volumes of chloroform: methanol in the ratio 2:1 was added and the mixture was acid to $\mathrm{pH} 2.0$ using $6 \mathrm{~N} \mathrm{HCl}$ and kept overnight for evaporation. Finally white colour precipitation was seen between the two liquid layers i.e., supernatant and chloroform: methanol. The same was then collected and lyophilized and characterized using FTIR.

\section{Characterization of biosurfactant by FTIR analysis}

For FTIR measurements, the Ag nanoparticles solution was centrifuged at 10,000 rpm for $30 \mathrm{~min}$. The pellet was washed three times with $20 \mathrm{ml}$ of de-ionized water to get rid of the free proteins/ enzymes that are not capping the silver nanoparticles. The samples were dried and grinded with $\mathrm{KBr}$ pellets and analyzed on a Shimadzu IR-IR Affinity1 model in the diffuse reflectance mode operating at a resolution of 4 $\mathrm{cm}-1$.

\section{GC-MS (Gas Chromatography Mass Spectrometry)}

GC-MS technique was used in the study to identify the components present in the sample. GC-MS analysis of this sample was performed using a Perkin Elmer GC Clarus 500 systems and chromatography interfaced to a silica capillary column (30mx $1 \mu 1$ was Mdf. Composed of $100 \%$ Dimethyl poly siloxane) for GC-MS detection. An electron ionization energy system with ionization energy of $70 \mathrm{eV}$ was used. Helium gas (99.999\%) was used as the carrier gas at a constant flow rate of $1 \mathrm{ml} / \mathrm{min}$ and an injection volume of $2 \mu 1$ was employed (split ratio of 10:1). Injector temperature was $250^{\circ} \mathrm{c}$. The oven temperature was programmed from $110^{\circ} \mathrm{c}$ (isothermal for 2 mins) with an increase of $10^{\circ} \mathrm{c} / \mathrm{min}$ to $200^{\circ} \mathrm{C}$, then $5^{\circ} \mathrm{c} / \mathrm{min}$ to $280^{\circ} \mathrm{C}$ ending with $9 \mathrm{~min}$ isothermal at $280^{\circ} \mathrm{c}$. Mass spectra were taken at $70 \mathrm{eV}$, a scan interval of 0.5 seconds and fragments from 45 to $450 \mathrm{Da}$. Total GC running time was $36 \mathrm{mins}$. The relative percentage amount of each component was calculated by comparing its average peak area to the total areas. Software adopted to handle mass spectra and chromatograms was a Turbomass Version 5.2.0. Compound identification was obtained by comparing the retention times with those of authentic compounds and the spectral date obtained from library data of the corresponding compounds. The given sample was extracted by ethyl acetate and analysed in GC-MS for different components.

\section{Estimation of biosurfactant}

The biosurfactant activity had been estimated by using the orcinol method. The rhamnose had been prepared for 100 $\mathrm{mg}$ and it had estimated by using our sample, water and orcinol reagent. Then it would keep at $80^{\circ} \mathrm{C}$ for 10 mins in the water bath. Then the $\mathrm{nm}$ had been identified in the UVspectrophotometer. The precipitated silver nano particles were isolated by centrifugation at $15,000 \mathrm{rpm}$. This procedure results in the production of silver nano sized particle. The particles where then sonicated in $10 \mathrm{ml}$.

\section{Synthesis of Silver Nanoparicles:}

The synthesis of silver nano particles in the water in oil micro emulsion phase was performed by the addition of synthesized two reverse micelles in the presence of reducing agent.The synthesis involves mixing up to $0.5 \mathrm{~m} / 1$ aqueous silver nitrate solution, $3.0 \mathrm{~g}$ of biosurfacatant, $1.5 \mathrm{~g}$ of butanol together and stirred thoroughly at room temperature until homogeneous reverse micelles were formed.

\section{Characterization of silver nanoparticles: UV-VIS spectra analysis}

The bio reduction of $\mathrm{Ag}+$ ions in solution was monitored in optimal measurement, which carried out by using UVVisible spectrophotometer and scanning the spectra between $200-800 \mathrm{~nm}$ at the reduction of $1 \mathrm{mn}$. 


\section{EDAX (ENERGY DISPENSIVE $X$ RAY SPECTRA ANALYSIS)}

EDX pattern shows the crystalline and elemental composition of silver nanoparticles synthesized from the biosurfactant producing organism. The strong signal in the silver region was observed at $3 \mathrm{keV}$ for silver nanoparticles due to the surface Plasmon resonance.A weak signal from ' $\mathrm{O}$ ' is recorded it may due to the presence of organic moieties from the enzymes or proteins in the extract.

\section{SEM (Scanning Electron Microscope)}

The SEM image showing the high intensity of silver nanoparticles synthesized by biosurfactant producing organism further confirmed the development of silver nanostructures. SEM provided further insight into the morphology and size details of the silver nanoparticles. SEM analysis showed the particle size of about $100 \mathrm{~nm}$ as well the crystal structure of the nanoparticles. The silver nanoparticles synthesized via green route are highly toxic to multidrug resistant bacteria hence has a great potential in Biomedical applications.

\section{Antimicrobial activity}

The well diffusion method had been used for the antimicrobial activity studies. The Muller Hinton Agar had been prepared. The sample supernatant had been added in the wells. Incubate the plates at $37^{\circ} \mathrm{C}$ for 24 hours. After incubation the zone of inhibition had been formed and the zones had been measured in millimeters using the scale.

\section{RESULT AND DISCUSSION}

\section{Isolation of Bacteria}

Five strains observed different colony morphology were streaked on nutrient agar plate to obtain pure culture and they were taken for further study. Out of five, isolates 5 produced pink coloured non diffusible pigment producing colonies and the colony morphology.

\section{Staining characters}

All the five bacterial isolates reviewed in this study were stained by Gram's stain. All the five isolates were Gram negative. The morphology details of the bacteria.

\section{Isolation of biosurfactant producing organisms}

5 Bacterial isolates were screened as a biosurfactant producer and then the bacterial isolates were identified based on biochemical tests and Bergy's Manual classifications. The isolates are as followed,

$>$ E.coli

$>$ Pseudomonas sp.

$>$ Klebsiella sp.

$>$ Vibrio $s p$.

$>$ Serratia sp.

Table 1: Results of colony morphology and Biochemical tests of bacterial isolation

\begin{tabular}{|l|c|c|c|c|c|}
\hline \multicolumn{1}{|c|}{ Isolates/characters } & $\mathbf{1}$ & $\mathbf{2}$ & $\mathbf{3}$ & $\mathbf{4}$ & $\mathbf{5}$ \\
\hline Type of bacteria & Aerobic & Aerobic & Aerobic & Aerobic & $\begin{array}{c}\text { Facultative } \\
\text { Anaerobic }\end{array}$ \\
\hline Colonies & White & White & White & Yellowish white & Pink colour \\
\hline Gram's staining & Gram negative & Gram negative & $\begin{array}{c}\text { Gram } \\
\text { negative }\end{array}$ & Gram negative & Gram negative \\
\hline Morphology & $\begin{array}{c}\text { Rods in chains } \\
\text { with terminal } \\
\text { spores }\end{array}$ & $\begin{array}{c}\text { Rods in chains } \\
\text { with terminal } \\
\text { spores }\end{array}$ & $\begin{array}{c}\text { Rods in } \\
\text { chains }\end{array}$ & $\begin{array}{c}\text { Straight rods in } \\
\text { single }\end{array}$ & $\begin{array}{c}\text { Straight rods in } \\
\text { single or in pairs }\end{array}$ \\
\hline $\begin{array}{l}\text { Straight rods in single or in } \\
\text { pairs }\end{array}$ & - & - & - & + & - \\
\hline Methyl red & - & - & - & + & + \\
\hline VogesProskauer & - & - & + & + & + \\
\hline Citrate utilization & + & + & - & - & - \\
\hline H2S production & - & - & + & - & + \\
\hline Urease & + & - & - & + & + \\
\hline $\begin{array}{l}\text { O-nitrophenyl- } \beta \text {-D-galacto } \\
\text { pyranoside (ONPG) }\end{array}$ & - & - & + & + & - \\
\hline Phenylalanine deamination & - & + & + & + & + \\
\hline Nitrate reduction & + & + & & + \\
\hline Ornithine utilization & & + & + & + \\
\hline
\end{tabular}




\section{Screening of Biosurfactant}

\section{CTAB methylene blue agar method}

In the $\mathrm{CTAB}$, methylene blue agar medium after the 24 hours of incubation the biosurfactant activity of blue color zone had been formed. In the CTAB agar plate the organism Pseudomonas sp, Serratia sp, E. coli and Klebsilla sp, had shown the positive result Serratia sp. shows high zone and it was used for further studies. Nwaguma et al., [4] reported that the selected isolates were performed with different screening test to check the biosurfactant production ability and to find the efficient biosurfactant producer by $\mathrm{CTAB}$ plate assay

\section{Determination of emulsification index}

The height of the emulsion layer was measured after $24 \mathrm{hr}$ to determine the sample emulsification index. The equation used to determine the emulsification index $\left(\mathrm{E}_{24}(\%)\right)$ is as follows

$\mathrm{E}_{24}(\%)=$ (height of emulsion layer/ height of total solution) $* 100 \%$

Table 2: Emulsification Activity of Bacterial Isolates

\begin{tabular}{|c|c|c|}
\hline S.No & SAMPLE & $\begin{array}{c}\text { TOTAL LENGTH } \\
\left(\mathbf{E}_{\mathbf{2 4}} \mathbf{\%}\right)\end{array}$ \\
\hline 1 & $\begin{array}{c}\text { Pseudomonas } \\
\text { sp. }\end{array}$ & $68 \%$ \\
\hline 2 & E. coli & $68 \%$ \\
\hline 3 & Vibrio $s p$. & $64 \%$ \\
\hline 4 & Klebsiella sp. & $72 \%$ \\
\hline 5 & Serratia $s p$. & $76 \%$ \\
\hline
\end{tabular}

The emulsification index of the organism Pseudomonas $s p$, Serratia sp, E. coli and Klebsilla sp had shown above $50 \%$. Serratia sp. shows high emulsification index and it was used for further studies.

\section{Blood haemolysis test}

In the blood haemolysis test, the organism had get haemolysed in the blood agar medium. The blood agar had get haemolysed by Serratia sp. cell free supernatant. Dhail and Jasuja [5] studied that haemolytic activity assay, and emulsification activity measurement was used to screen the biosurfactant producer.

\section{Estimation of biosurfactant}

The surface tension of the culture medium decreased to a maximum extent of $26.5 \mathrm{mN} / \mathrm{m}$ after $72 \mathrm{~h}$ of incubation. Furthermore, the CMC of the crude biosurfactant produced by Serratia $s p$. was estimated at $60.13 \mathrm{mg} / \mathrm{l}$.

\section{Extraction and characterization of biosufactant}

The biosurfactant was extracted by acidification method from cell free supernatant of Serratia $s p$. This was used for FTIR and GCMS studies.

\section{FTIR analysis of biosurfactant}

The functional group of the partially purified biosurfactant was investigated for the chemical nature of the biosurfactant using FTIR. The IR spectrum was collected in the range of $4000-428 \mathrm{~cm}^{-1}$. The absorption peaks are observed at $1641,1506,1352,1217,1055$ and $695 \mathrm{~cm}^{-1}$. An intense broad absorbance at $3259 \mathrm{~cm}^{-1}$ results due to the strong broad stretch $\mathrm{H}$-bonded of $\mathrm{O}-\mathrm{H}$ of alcohol group. The band at 454 and $480 \mathrm{~cm}^{-1}$ assigned to the approximate $\mathrm{C} \equiv \mathrm{C}$ stretching modes of alkynes. The band at $428 \mathrm{~cm}^{-1}$ can be assigned to the $\mathrm{N}-\mathrm{H}$ stretch vibrations of primary amines. The band at 554 and $600 \mathrm{~cm}^{-1}$ represents C-H-OOP and Potassium Bromide strong stretch of aromatic anhydrides and alkyl halide respectively. Rahman et al. [6] studied the molecular structure of the rhamnolipids with the help of FTIR spectroscopy. Strong and broad bands of the hydroxyl group free $(-\mathrm{OH})$ stretch due to hydrogen bonding were observed in the region $(3368 \mathrm{~cm}-1)$. The presence of carboxylic acid functional group in the molecule was confirmed by the bending of the hydroxyl $(\mathrm{O}-\mathrm{H})$ of medium intensity bands in the region of $1455-1380 \mathrm{~cm}-1$. The aliphatic bonds $\mathrm{CH} 3, \mathrm{CH} 2$ and $\mathrm{C}-\mathrm{H}$ stretching with strong bands are shown in region of $2925-2856$ and 1455-1380 $\mathrm{cm}-1$.



Fig 1: FTIR analysis of biosurfactant from Serratia $s p$.

\section{GC-MS Analysis}

GC-MS is an analytical method comprising of gas chromatography coupled to mass spectroscopy for identification of different substances in the sample. GC-MS chromatogram of the biosurfactant producing organism was performed, showing six peaks indicating the presence of different compounds (Figure 2). Major peak compounds at the retention time of $11.59,12.47,13.84,14.48,18.16,19.78$ minutes were identified from the standard library compound as 5- methyl-Z-5 docosene, hexadecanoic acid, 3hydroxydecanoic acid, trans-2-dodecenoic acid, Nhexadecanoic acid, 2(1H)-benzocyclooctenone respectively. Therefore, the study indicates rhamnolipid biosurfactant. 


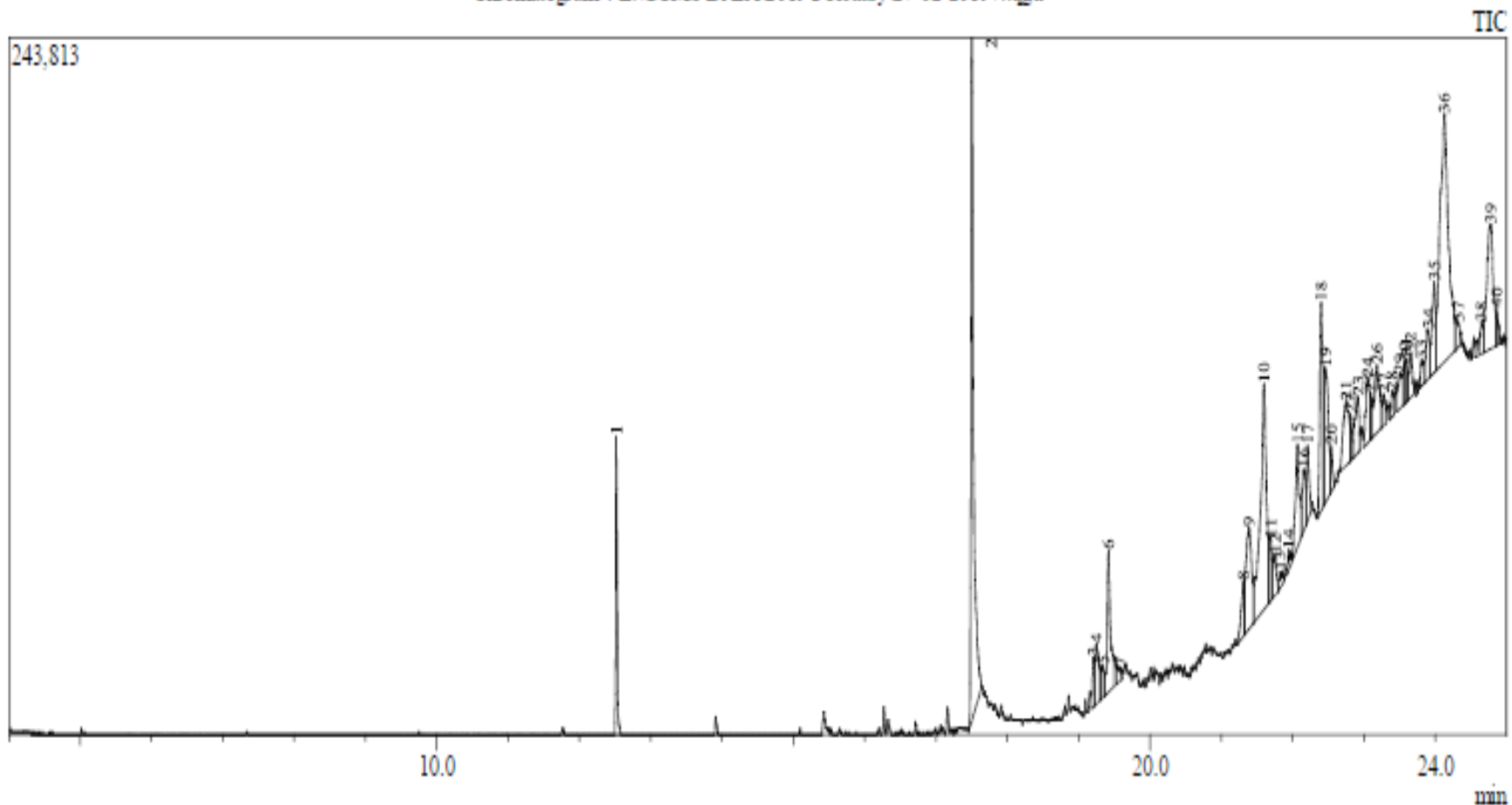

CompName:Glycine, 2-cyclohexyl-N-(but-3-yn-l-yl)osycabonyl-, tidecyl ester

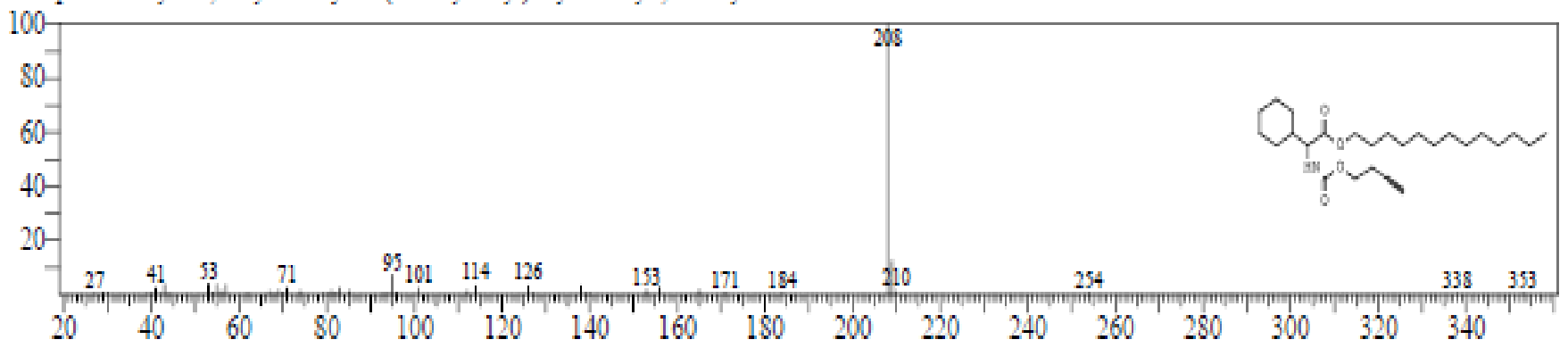

CompName:HEXADECANOIC ACD, 2-HYDROXY-1-(HYDROXYMETHYL)ETHYL ESTER SS 2-HYDROXY-1-(HYDROXYMETHYL)ETHYL PA]

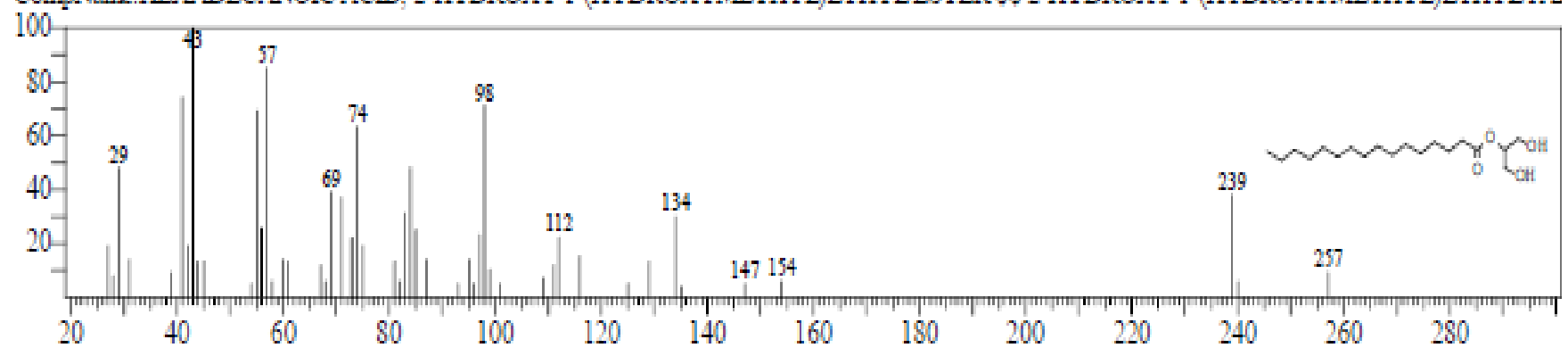

Fig 2: GC MS Analysis of biosurfactant from Serratia sp.

\section{Synthesis of silver nano particles}

UV-visible spectra of the marine water biosurfactant are synthesised by Silver nanoparticles. The contaminants present in the marine water biosurfactants absorb at higher wavelengths $(300-700 \mathrm{~nm})$ while the pure biosurfactants absorb only in the far UV region of the spectrum. Das et al. [7] reported the extracellular synthesis of silver nanoparticles by the Bacillus strain CS 11. The size of silver nanoparticles obtained was in 42 - $92 \mathrm{~nm}$ range. Jaffat, et al., [8] confirmed the nanoparticles synthesis from Lactobacillus Mixtures. 
SYSTRONICS

UV-VIS Spectrophotometer: 119

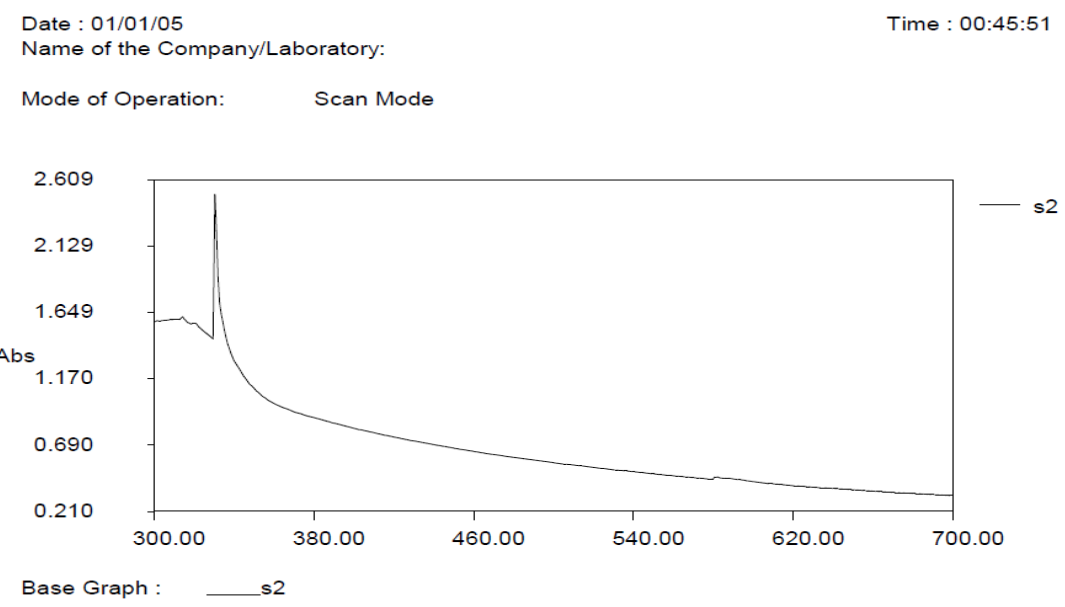

Fig 3: The UV-Visible absorbance spectrum of silver nanoparticles which the peak hbeen formed in $350 \mathrm{~mm}$

\section{EDAX result}

Determine the elemental composition of synthesized nanoparticles EDAX analysis was performed. In the EDAX spectra of Ag Nanoparticles, the most intense peak around 3 key corresponds to binding energies of Ag. Hence it was confirmed the formation of AgNPs. The remaining elements were due to presence of biosurfactant producing organism serratia sp. Silver Nano crystallites display an optical absorption band peak at approximately $3 \mathrm{keV}$, which is typical of the absorption of metallic silver Nano crystals due to surface Plasmon resonance. Corresponding band peak was obtained in same AgNPs synthesized from the organism serratia sp. EDS confirmed the Presence of the signal characteristic of elemental silver. Silver Nano crystallites display an optical absorption band peak at approximately 3 $\mathrm{keV}$, which is typical of the absorption of metallic silver Nano crystals due to surface Plasmon resonance [9].

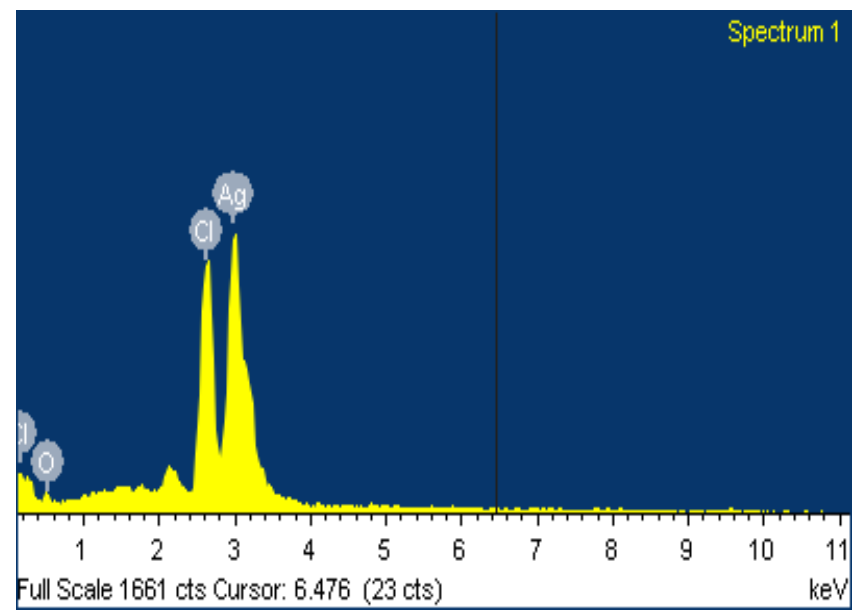

Fig 4: EDAX analysis shows the elemental composition of synthesized nanoparticles. The elemental composition of synthesized nanoparticles by EDAX analysis
Table 3:

\begin{tabular}{|c|c|c|}
\hline Element & Weight\% & Atomic\% \\
\hline $\mathrm{O} \mathrm{K}$ & -0.07 & -0.31 \\
\hline $\mathrm{Cl} \mathrm{K}$ & 24.69 & 50.07 \\
\hline $\mathrm{Ag} \mathrm{L}$ & 75.38 & 50.24 \\
\hline Totals & 100.00 & \\
\hline
\end{tabular}

SEM Result

SEM analysis was carried out to understand the topology of Ag nanoparticles, which showed the synthesis of mono dispersed spherical Ag nanoparticles. In the family of electron microscopy techniques the sample is exposed to a high energy focused beam of electrons. In scanning electron microscopy (SEM) the interaction of the beam with the particle surface are scanned over the sample and measured as secondary electrons (most common), or backscattered electrons or X-ray photons. Due to the high depth of field in SEM a three dimensional appearance can be obtained. The sample needs to be conductively coated with gold or graphite and maintained under ultrahigh vacuum in order not to have the secondary electrons interact with gas molecules. The substrate is typically a filter membrane or a conducting grid.

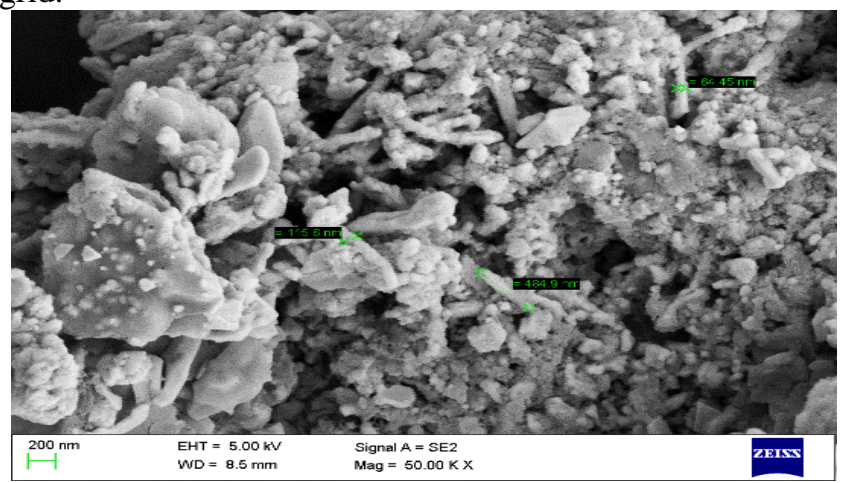




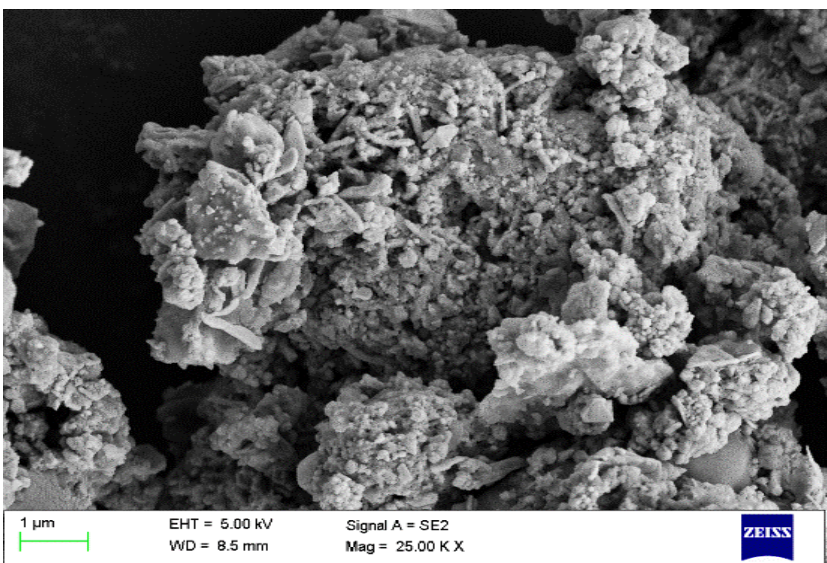

Fig 5: SEM analysis of Ag nanoparticles from biosurfactant of Serratia sp.

\section{Antimicrobial activity of biosurfactant by well diffusion method}

The antimicrobial activity of organism serratia $s p$. which was synthesized by silver nanoparticles was studied in different concentrations $(5,25,50,100$ and 250) against the organism E.coli (gram negative bacteria). The antimicrobial potential of the organism were assessed in terms of Zone of inhibition of bacterial growth [10]. A number of studies exist which reports the Antimicrobial activity of extracellular synthesized biosurfactant silver nanoparticles isolated from various bacterial strains [11].

\section{CONCLUSION}

The Serratia $s p$. was isolated from the marine water which had been collected from marina beach, Chennai, Tamilnadu. The isolated organism was screened for the production of biosurfactant. The screening process had been used by CTAB method, blood haemolysis method, emulsification activity. Then the silver nanoparticles get synthesized by using the organism serratia $s p$. and the wavelength had been measured in the graphical representation in the UV- visible spectrophotometer. Then the characterization process had been done by using the methods of FTIR, SEM, GCMS and EDAX. These methods clearly show about the compounds present in the organisms and it shows the graphical representation.

\section{ACKNOWLEDGEMENT}

The authors owe a debt of gratitude to the Vanetra Muthayammal College of Arts and Science for the Research support.

\section{CONFLICT OF INTEREST}

The authors declare that they have no conflict of interest.

\section{REFERENCE}

[1] S.K. Satpute, "Assessment of different screening methods for selecting biosurfactant producing marine bacteria", Ind. J. Mar. Sci., Vol. 3, Issue. 7, pp. 243-250, 2008.

[2] K. K Gautam, and V. K. Tyagi, "Microbial surfactants: A review". J. Oleo. Sci., Vol. 55, pp.155-166, 2005.

[3] P. C. Nagajyothi, and K.D. Lee, "Synthesis of Plant-Mediated Silver Nanoparticles Using Dioscoreabatatas Rhizome Extract and Evaluation of Their Antimicrobial Activities", J. Nanomaterials, pp. 1-7, 2011.

[4] I.V. Nwaguma, C.B. Chikere, and G.C. Okpokwasili, "Isolation, characterization, and application of biosurfactant by Klebsiella pneumoniae strain IVN51 isolated from hydrocarbon-polluted soil in Ogoniland, Nigeria", Bioresour. Bioprocess, Vol.3, Issue. 40, 2016.

[5] S. Dhail, and N.K. Jasuja, "Isolation of biosurfactant producing marinebacteria", African journal of environmental science technology. Vol. 6, Issue. 6, pp. 263-266, 2012.

[6] P.K.S.M. Rahman, G. Pasirayi, V. Auger, and Z. Ali, "Production of rhamnolipid biosurfactants by Pseudomonas aeruginosa DS10129 in a microfluidic bioreactor", Biotechnology and Applied Biochemistry, Vol. 55, Issue. 1, pp.45-52, 2010.

[7] A. J. Das, R. Kumar, S. P. Goutam, and S. S. Sagar, "Sunlight irradiation induced synthesis of silver nanoparticles using glycolipid bio-surfactant and exploring the antibacterial activity", Journal of Bioengineering and Biomedical Science, Vol. 6, Issue. $5,2016$.

[8] H. S. Jaffat, N. H. Aldujaili, and A. J. Abdul Hassan, "Antimicrobial Activity of Silver Nano Particles Biosynthesized by Lactobacillus Mixtures", Research Journal of Pharmaceutical, Biological and Chemical Sciences, Vol. 8, Issue. 1, pp. 19111924, 2017.

[9] E. Ranganath, V. Rathod, and A. Banu, "Screening of Lactobacillus spp. for Mediating the Biosynthesis of Silver Nanoparticles from Silver Nitrate", IOSR Journal of Pharmacy, Vol. 2, Issue. 2, pp. 237-241, 2012.

[10] T. Deepa Singh, P. Sravani, S. P. Sreedhar Bhattar, and K. Anuradha, "Green synthesis of iron, copper and silver nanoparticles and their antibacterial activity on animal pathogens - A Comparative study", Int. J. Sci. Res. in Biological Sciences, Vol. 6, Issue. 1, pp.19-24, 2019.

[11] P. R. Chaudhari, S. A. Masurkar, V. B. Shidore, and S. P. Kamble, "Antimicrobial activity of extracellularly synthesized silver nanoparticles usingvLactobacillus species obtained from VIZYLAC Capsule", Journal of Applied Pharmaceutical Science, Vol. 2, Issue. 3, pp. 25-29, 2012. 